\title{
Training Gesture-Based-Scroll Visual Artificial Intelligence And Measuring Its Effectiveness Using Hidden-Markov Modeling Methods
}

\author{
Arif Wibisono'. \\ ${ }^{1}$ Information Technology Education Study Program, Faculty of Mathematics Education Natural \\ Sciences and Information Technology, University of the Indonesian Teachers Association, \\ Semarang, Indonesia \\ Email: ${ }^{1}$ arifwibisono@upgris.ac.id
}

\begin{abstract}
In this article I discuss the method of hand gesture recognition as a visual motion detection based on artificial intelligence by training three main movements namely, scrolling up, scrolling down and stopping based on capturing the front camera image capture speed of $3 \mathrm{fps}$ and measuring its efficiency against the control movements that performed using Hidden-Markov Modeling (HMM) with each catch object scroll up 3 fps / 15 frames scroll down scroll down 3 fps / 15 frames and stop 3 fps / 9 frames, the result is that the most effective hand gesture object training movement is stop gesture with $3 \mathrm{fps} / 9$ frames because the object's movement is able to be recognized by the system only in the 3 rd second image capture frame.
\end{abstract}

Keywords: gesture-based-scroll, visual artificial intelligence, hidden-markov modeling

\section{INTRODUCTION}

The development of pointing system technology on computers is developing so rapidly starting from the mouse, fingermouse which is a revolution of the development of conventional computer mice where the user only moves the pointer and keyboard without making physical touch on the device [1], until the development of touch screen technology that using the principle of infrared emitter detectors [2] which are currently rife in computer and smartphone devices. In this research the researchers tried to review a new technology pointing system on a computer that uses sensi movements, especially sensi gesture and artificial intelligence technology. Referring to research [3] that uses hand gesture recognition technology researchers try to apply similar technology assisted by artificial intelligence who are trained to create hand-gesture-based computer pointing system technology. 


\section{METHODS}

The research method used was an experiment with testing using Hidden Markov Model (HMM) modeling, HMM processes training data, in the form of 3 main movements, namely Scroll Up-Scroll Down \& Scroll-Stop. The stages of this study there are only 3 main parts, namely (1) taining hand gesture, for processing visual artificial intelligence (2) testing the effectiveness of training conducted using the Hidden Markov Model (3) the most effective training conclusions and determining the influencing factors.

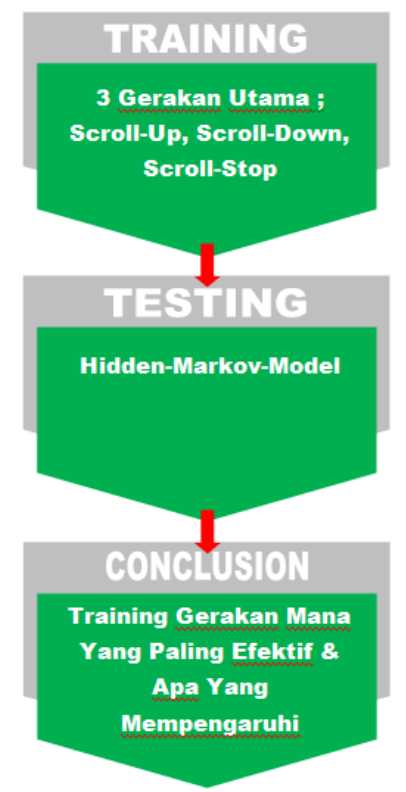

Figure 1. Research Methods were adapted from experimental research methods (Kirk, 1982; Oehlert; 2000) in a book entitled "Research Methods in Human-Computer Interaction" (Jonathan Lazar; Jinjuan Heidi Feng; Harry Hochheiser (2017)) [14]

\subsection{System Performance}

System performance is measured based on the following parameters:

1. System Accuracy

Accuracy is a measure of system accuracy in recognizing hand gestures and matching them with data that has been previously trained and matching them. The system acquisition can be done mathematically as in equation 1 and 2 below.

$$
E R=\frac{\text { Jumlah Hand Recoqnition Yang Salah }}{\text { Jumlah Training Frame Keseluruhan }} \times 100 \%
$$


Vol. 2, No. 1, March 2020

$$
\text { Akurasi }=\frac{\text { Jumlah Hand Recoqnition Yang Benar }}{\text { Jumlah Training Frame Keseluruhan }} \times 100 \%
$$

2. Computation Time

Computational time is the time needed for the system to perform a process. In this system, computational time is calculated using Excel calculations, so that the system computing is obtained.

\section{RESULTSANDDISCUSSION}

\subsection{System Testing Scenarios}

The scenarios used to recognize hand gestures are as follows:

1. Performing the training process of 3 main motion simulations, namely: scroll-up, scroll-down, and scroll-stop, and obtained technical data as follows:

Tabel 1. Technical data from trial results

\begin{tabular}{llll}
\hline & Capture Speed & $\begin{array}{l}\text { The number } \\
\text { of pictures } \\
\text { taken }\end{array}$ & $\begin{array}{l}\text { many } \\
\text { variations of } \\
\text { movement }\end{array}$ \\
\hline $\begin{array}{l}\text { Scroll Down Visual } \\
\text { Hand-Gesture }\end{array}$ & $3 \mathrm{fps}$ & 15 frames & 1 \\
\hline $\begin{array}{l}\text { Scroll Up Visual } \\
\text { Hand-Gesture }\end{array}$ & $3 \mathrm{fps}$ & 15 frames & 1 \\
\hline $\begin{array}{l}\text { Scroll Stop Visual } \\
\text { Hand-Gesture }\end{array}$ & $3 \mathrm{fps}$ & 9 frames & 1 \\
\hline
\end{tabular}

2. Visual testing of the effectiveness of the training conducted.

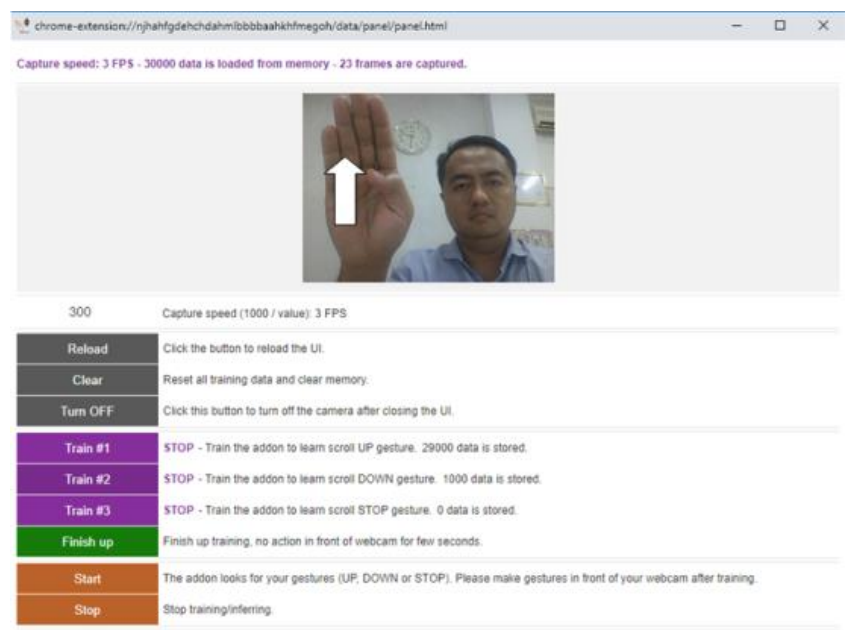

Figure 2.Scroll Up Visual Hand-Gesture Capture Speed 3fps 
Journalof Information Systems and Informatics

Vol. 2, No. 1, March 2020

p-ISSN: 2656-5935 http://journal-isi.org/index.php/isi e-ISSN: 2656-4882

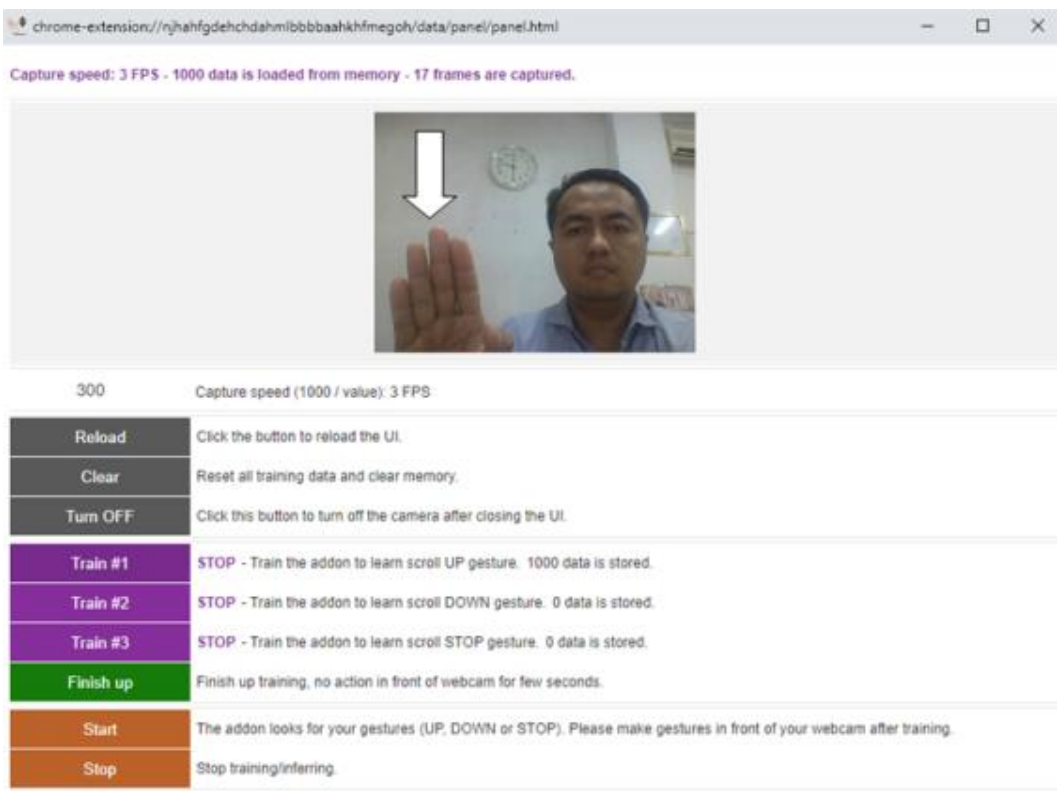

Figure 3.Scroll Down Visual Hand-Gesture Capture Speed 3fps

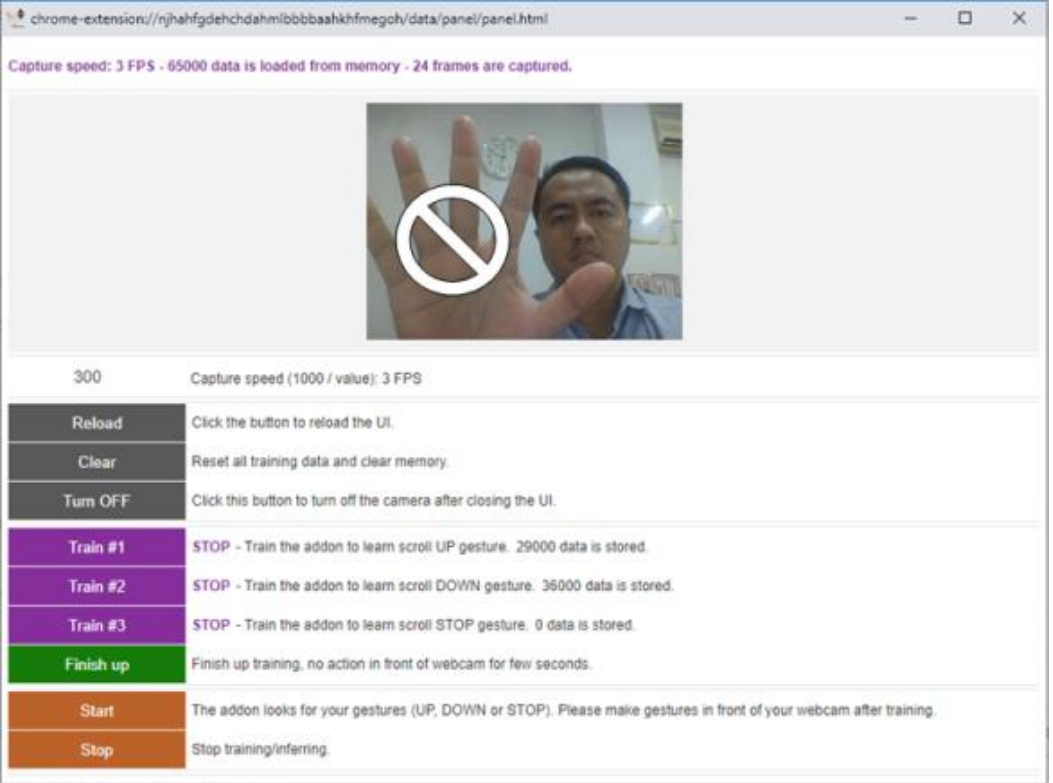

Figure 4.Scroll Stop Visual Hand-Gesture Capture Speed 3fps

3. Measuring system performance, including accuracy and computational time 


\subsection{Systems Testing Analysis}

1. The result of calculating the error of hand-gesture recognition based on Error Rate (ER) is poured into the following graph:

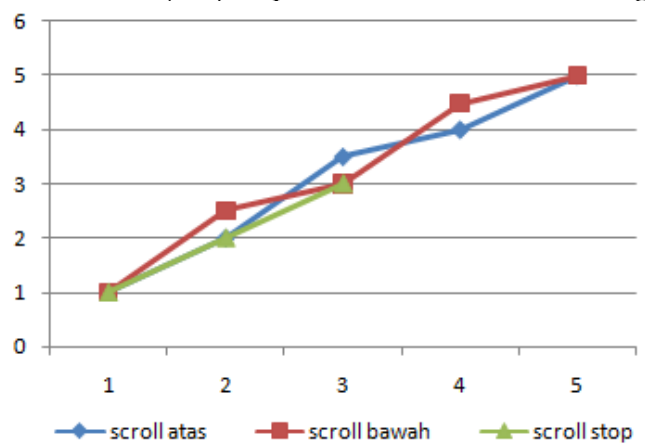

2. Comparing ER average results and HMM training times in the handgesture response system to the HMM state increase. As stated in the following graph:

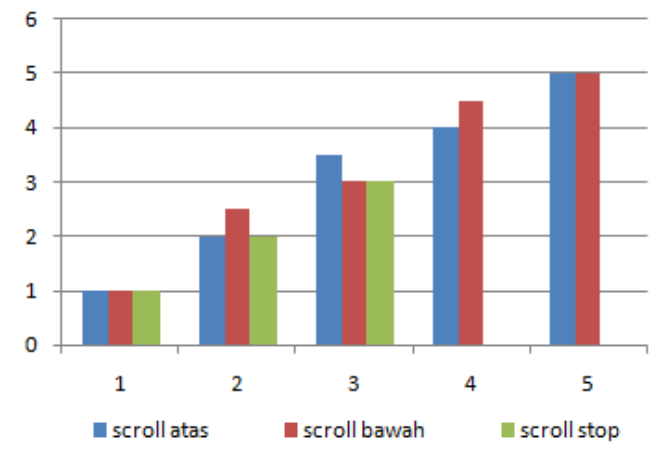

\section{CONCLUSION}

Using Hidden-Markov (HMM) modeling with each catch object scrolling up to 3 fps / 15 frames scrolling down 3 fps / 15 frames and stop 3 fps / 3 frames, the result is that the most effective hand gesture object training movement is stop gesture with $3 \mathrm{fps} / 9$ frames because the object's movement is able to be recognized by the system only at the 3 rd second image capture frame.

\section{REFERENCES}

[1] L. Barkhuus, "UbiComp 2002 international conference," Ubiquitous Comput. Transpar. Context. Mob. Comput., pp. 67-68, 2002.

[2] T. Hoye and J. Kozak, "Tenth Annual Freshman Conference Touch Screens: a Pressing Technology Infrared Touch Screens,” pp. 1-6, 2010. 
[3] M. Correa, J. Ruiz-Del-Solar, R. Verschae, J. Lee-Ferng, and N. Castillo, "Real-time hand gesture recognition for human robot interaction," Lect. Notes Comput. Sci. (including Subser. Lect. Notes Artif. Intell. Lect. Notes Bioinformatics), vol. 5949 LNAI, no. June, pp. 46-57, 2010, doi: 10.1007/978-3-642-11876-0_5.

[4] Z. Ren, J. Yuan, J. Meng, and Z. Zhang, "Robust Part-Based Hand Gesture Recognition Using Kinect Sensor," IEEE Trans. Multimed., vol. 15, no. 5, pp. 1110-1120, 2013, doi: 10.1109/TMM.2013.2246148.

[5] M. Correa, J. Ruiz-Del-Solar, R. Verschae, J. Lee-Ferng, and N. Castillo, "Real-time hand gesture recognition for human robot interaction," Lect. Notes Comput. Sci. (including Subser. Lect. Notes Artif. Intell. Lect. Notes Bioinformatics), vol. 5949 LNAI, no. May 2014, pp. 46-57, 2010, doi: 10.1007/978-3-642-11876-0_5.

[6] V. Sutojo, T; Mulyanto, Edi; Suhartono, "Kecerdasan Buatan," pp. 211235, 2011.

[7] S. Russell and P. Norvig, "Artificial Intelligience: a modern approach." p. 1151, 2016, doi: 10.1017/CBO9781107415324.004.

[8] Id.techinasia.co, "vision-ai-penerapannya-di-industri." [Online]. Available: https://id.techinasia.com/vision-ai-penerapannya-di-industri. [Accessed: 01-Mar-2020].

[9] E. F. Yuwitaning, B. Hidayat, and N. Andini, "Implementasi Metode Hidden Markov Model untuk Deteksi Tulisan Tangan," e-Proceeding Eng., vol. 1, no. 1, pp. 396-402, 2014.

[10] A. han, Muhammad \& Malik, Rabbiya \& Siddique, Ayesha \& Nawaz, "citation-332392507." Elsevier B.V., Netherlands, doi: https://doi.org/10.1016/j.ijleo.2019.04.068.

[11] B. H. Juang and L. R. Rabiner, "Hidden Markov Models for Speech Recognition," Technometrics, vol. 33, no. 3, pp. 251-272, Aug. 1991, doi: 10.1080/00401706.1991.10484833.

[12] A. Wijaya, "APLIKASI HIDDEN MARKOV MODEL PADA PINTU GESER BERBASIS SUARA." Perpustakaan Universitas Snata Darma Yogyakarta, Yogyakarta, 2011.

[13] A. K. Nisa", "Aplikasi Metode Hidden Markov Model Untuk Identifikasi Wajah Individu," p. 124, 2017.

[14] J. L. H. F. Hochheiser, Research Methods in Human-Computer Interaction. 50 Hampshire Street, 5th Floor, Cambridge, MA 02139, United States: Morgan Kaufmann Publisher An Imprint Of Elsevier. 